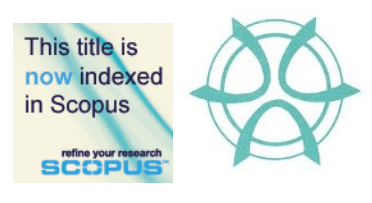

PLANNING MALAYSIA:

Journal of the Malaysian Institute of Planners

VOLUME 19 ISSUE 5 (2021), Page 220 - 232

\title{
HOUSING CRISIS IN ALGERIA: CHALLENGES AND PERSPECTIVES
}

\author{
Djafri Riadh $^{1}$, Mariana Mohamed Osman ${ }^{2}$ \\ 1,2 Department of Urban and Regional Planning, \\ Kuliyyah of Architecture and Environmental Design \\ UNIVERSITI ISLAM ANTARABANGSA MALAYSIA
}

\begin{abstract}
The provision of good quality housing remains a major problem facing policymakers in developing countries, with Algeria being no exception. The Algerian policy focuses on ensuring the provision of housing to low-income households who cannot house themselves adequately. This article presents an overview of the Algerian housing policies focusing on the issues encountered by governments since independence in 1962. This entails presenting the history of Algerian housing policy, including colonial, after independence and new Algeria. This will not be completed without reviewing the different national housing plans and policies introduced by the Algerian government, focusing on the housing achievements and deficits. Using qualitative analysis of secondary data through narrative and inductive approaches, this research argues that a significant change in how these programmes are currently structured is urgent. Thus, there is a need to find a new approach to finance the construction of public and private housing units and reduce dependence on the Public Treasury.
\end{abstract}

Keywords: Housing; Algeria; Housing Crisis; Housing History; Housing Supply; Housing Performance

\footnotetext{
${ }^{2}$ Corresponding Author. Email: mariana@iium.edu.my
} 
PLANNING MALAYSIA

Journal of the Malaysia Institute of Planners (2021)

\section{INTRODUCTION}

Housing has become one of the main concerns in Algeria despite Algeria's housing policy having evolved since independence (1962) by implementing various housing policies and plans in order to tackle the housing issues (Algerian National Report on Housing, 2014; Merzag, 2015; Tarache, 2009). The Worldometer statistics illustrated the rapid growth of Algeria's urban population representing $72.6 \%$ of the global population (Worldometer, 2020). Demographic factors make the problem more acute as the Algerian population is growing around $1.85 \%$ per year. In addition, the Algerian National Report on Housing (2014) reported that urban areas were crowded, and the development of new suburban areas had become critical in Algerian cities. The rapid urban development was not accompanied by appropriate urban infrastructure thus failed to accommodate population growth within the cities.

Many studies (Madani, 2012; Merzag, 2015; Mohdeb, 1988; Tarache, 2009) have emphasised that Algeria is suffering from a housing crisis. The uncontrolled growth of population is a phenomenon that affects all countries of the third world including Algeria. In 2011-2015, the construction of residential buildings increased and was the largest, representing $41 \%$ of the total construction sector. (Oxford Business Group, 2017). According to the Algerian National Office of Statistics ONS (2017), the construction of housing has increased in recent decades to reach 1,531,518 units. Over the past decades, many studies (Behloul, 1991; Bellal, 2009; Madani, 2012; Merzag, 2015) considered that the issue of the housing shortage in Algeria is crucial. Nowadays, despite the considerable delivered number of housing units in Algeria, the problem of housing provision is still a major concern.

The Algerian authorities have implemented various programmes to upgrade the housing condition and offer more quality and decent housing (Djiar, Gharbi, Messaoudene, \& Chareb, 2015). Lalonde (2010) reported that the policies of urban planning during the colonial period were not suitable to the social and cultural characteristics of the local people at that time, which has worsened the housing situation. This has led to the creation of shantytowns. The French culture and politics influenced Algerian housing design during the colonisation period, where the objective during this period was to integrate the Algerian citizens into the culture of French society. In addition, the Algerian government after independence considered that the housing design inherited from the coloniser were suitable for the Algerian society at that time.

Many factors influence the production of housing units, the most important of which is the insufficient housing budget to fulfil the demand increasing after uncontrolled exodus and the maladjusted French housing to the Algerian society, with the augmentation of the family rate with almost seven persons on average (Benamrane, 1980; Ministry of Housing, 1986). According to Bendib \& Naceur (2018), collective housing in Algeria is characterised by 
Djafri Riadh, Mariana Mohamed Osman

Housing Crisis in Algeria: Challenges and Perspectives

outdoor spaces which are poorly maintained, suggesting no form of appropriation. This situation led to dysfunctions that stigmatised these areas as violence and unsecured neighbourhood areas. Therefore, urban interventions have been planned and carried out in the form of operations intended to improve the image of these residential areas. Unfortunately, they proved ineffective and were unable to achieve the expected objectives. This spatial fluidity was not adapted to the needs of users and given the State's inability to offer outdoor spaces that can be appropriated by inhabitants. Accordingly, there is a need to search for strategies of appropriation to provide solutions to their problems. This concerns all Algerian cities. Djafri, Mohamed Osman, Rabe, \& Shuid (2019) concluded that effective and innovative policy and programmes need to be planned with government agencies, public institutions and ministries together with other stakeholders in ensuring the provision of good quality housing for all can be achieved.

Despite the considerable effort and investment made by the Algerian government, Algeria is facing a pressing housing problem, in which the housing crisis worsens progressively (Abdelkarim, 2012; Bellal, 2009; Djafri et al., 2019; Guendouz, Gasmi, \& Belhimer, 2017; Hadjri, 1992; Madani, 2012; MouazizBouchentouf, 2018; Saada, 1999). The next section will discuss the Algerian housing policies from the colonial period till the new era

\section{Algerian Housing Policies From 1945 to 1999 Colonial Period 1945-1962}

In 1945, the situation in Algerian cities was critical, as the total housing was estimated at 850100 housing units and the average household size for the indigenous population was eight persons per housing unit. From 1945 to 1954, several houses were built, and the housing stock (informal housing excluded) has grown to 1220221 housing units, and the average household size has improved to 7.76 (Benmatti, 1982).

During the Algerian war (1954-1962), the French colonial authority excluded the Algerian society from the war by implementing a housing programme called the Constantine Plan (Plan de Constantine). It is an economic programme designed by the French government in 1958. It was developed to achieve the construction of 200000 urban housing units and 110000 rural housing units, allowing the accommodation of one million people. It was an attempt to improve the quality of life of Algerians living in rural areas (Djiar, 2014). Furthermore, the main objectives set by this plan were also the redistribution of 250000 hectares of agricultural land, the development of irrigation, the creation of 400000 industrial jobs for Algerians, raising national revenue by $7.5 \%$, and increase wages (Mouaziz-Bouchentouf, 2018). Nevertheless, the initiative did not achieve its objectives since it was used originally to eliminate the Algerian revolution. However, throughout the war 
(Algerian revolution), the rate of housing units fell in addition to the damages caused by this war increased the need for housing. As shown in Figure 1, the number of housing shortage increased significantly by more than 350000 units during this period.

After independence in 1962, Algeria listed nearly 1876000 housing units, which corresponded to an average household size of 6.1 persons (Djiar, 2014). As a result, new housing construction was not considered a priority at that time despite the housing shortage.

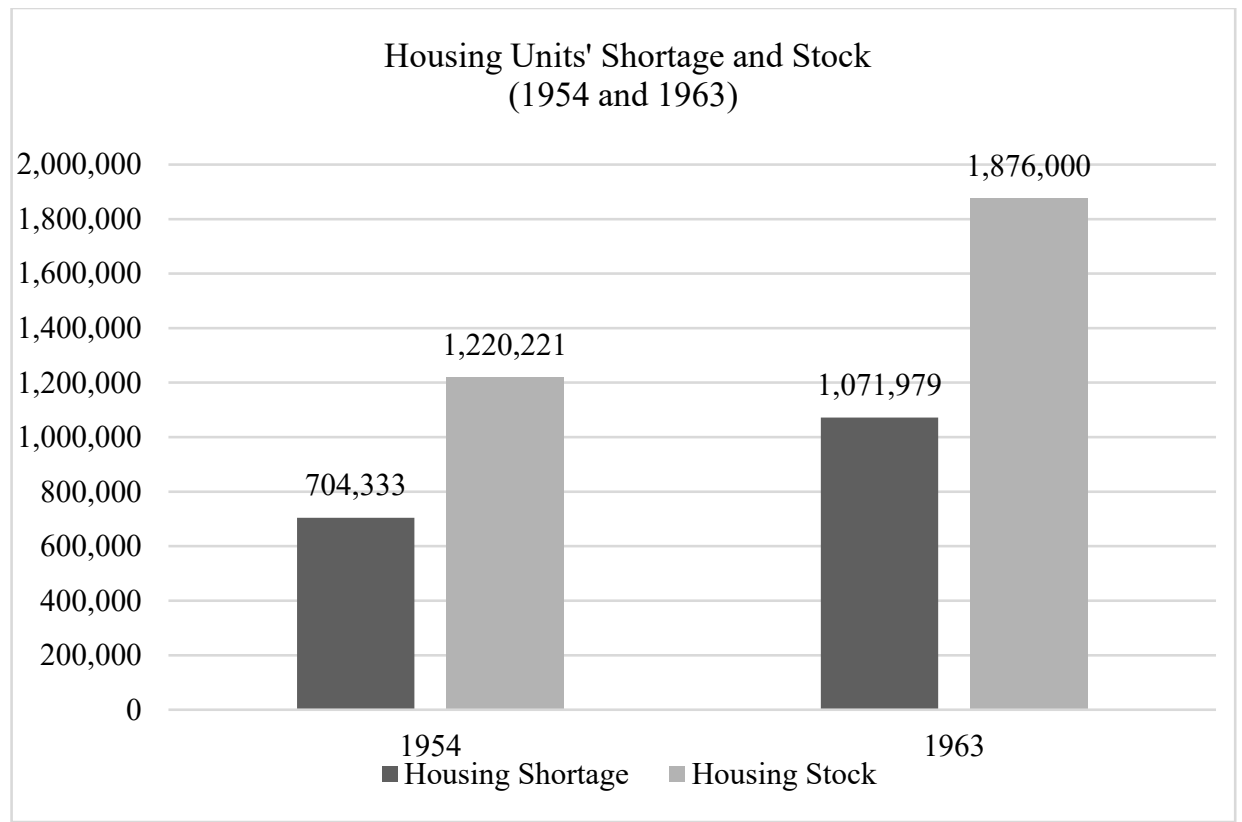

Figure 1: Housing Units' Shortage and Stock in 1954 and 1963 Source: Adapted by the author from Benmatti, 1982; Djiar, 2014

\section{After Independence 1963-1999}

In 1963, there was a deficit of 1071979 housing units for a population of 10288 000 inhabitants. This situation was caused by a disruption of administrative and executive structures, and a decline in the pace of construction (Benmatti, 1982). The causes of the housing crisis in Algeria are divided into three dimensions, namely historical with the colonial heritage and taking charge of housing after independence, socio-economic issue whereby migration has caused an increased demand for housing. In contrast, the economic condition remained insufficient to accommodate the increased demand (Tarache, 2009).

After independence, the Algerian government aimed to set up a vast industrialisation programme to create jobs and ease the housing crisis. Thus, housing planning was implemented through one three-year plan (1967-1969), two 
Djafri Riadh, Mariana Mohamed Osman

Housing Crisis in Algeria: Challenges and Perspectives

four-year plans (1970-1973 and 1974-1977), and two five-year plans (1980-1984 and 1985-1989). First, the 1967-1969 housing plan aimed mainly at reconstructing villages damaged by the war and completing abandoned construction sites. Second, 4000 housing units were built in urban areas in the 1970-1973 housing plan. Third, the housing sector received $13.25 \%$ of the national investment in the 1974-1977 housing plan. Fourth, the percentage of investment rose to $16.5 \%$ during the 1980-1984 housing plan (MouazizBouchentouf, 2018).

Since 1975, the Algerian government executed the ZHUN (New Urban Housing Zones) housing programme, which is an international housing model based on the concepts of prefabrication and standardisation. It was an attempt to solve the housing crisis and reduce the housing deficit in Algeria. The purpose of this policy was to construct a considerable number of new housing projects in order to solve the issues of social and physical environments. The objective, therefore, was to set and create new guidelines for designing new urban areas which meet the needs of occupants to increase their level of satisfaction (Oussadou, 1988). However, Naceur (2013) claimed that ZHUN housing programmes were incomplete or poorly finished and deprived of their required facilities. Thus, it failed to solve the housing crisis. In addition, the ZHUN was not the solution for the housing crisis at that time, as the average household size was increased in 1977 to 7.7 persons per housing unit and the housing deficit reached 1,268,585 units in 1977 with a stock of 2,208,712 housing units (Merzag, 2015).

From 1979, changes were introduced in the modes of financing since the housing issue captured the attention of public authorities after the creation of the Ministry of Housing in 1977. Moreover, starting from 1987, the average household size rose due to the augmentation of urban population. Accordingly, the percentage of urban population was increased from $49.7 \%$ to $58.3 \%$ in 1987 and 1998 respectively (Figure 2). 
PLANNING MALAYSIA

Journal of the Malaysia Institute of Planners (2021)

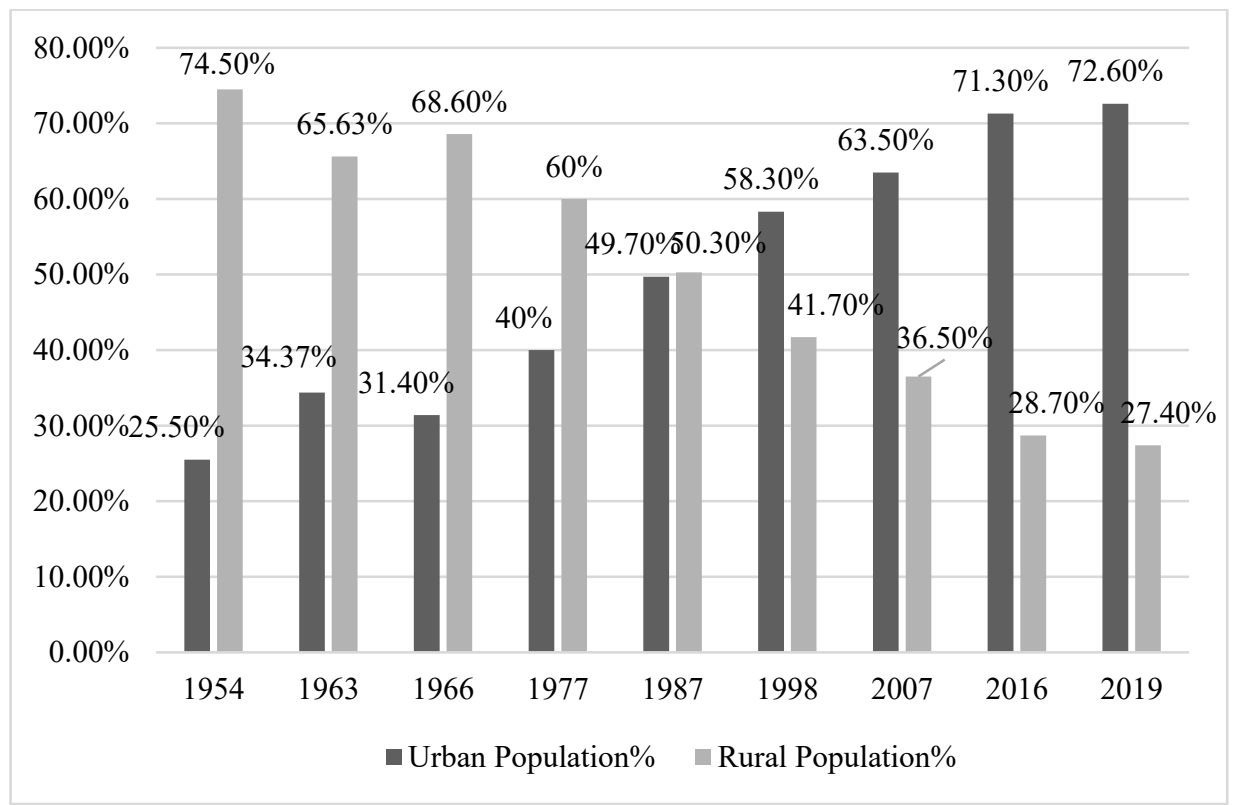

Figure 2: Evolution of the Urban and Rural Population 1954-2019 Source: ONS, 2000; The World Bank Group, 2017; Worldometer, 2020

In the early $90 \mathrm{~s}$, the housing crisis remained an obstacle for hundreds of thousands of Algerians despite the huge financial allocation dedicated to this sector. In terms of housing deficits and according to the statistics of the Ministry of Housing, Algeria's deficit in housing at the beginning of 1999 stood at approximately three million housing units (MHUV, 2018).

Since 1999, Algeria has recovered political and institutional stability. The financial situation improved as a result of rising oil prices, and a new era for the housing sector started. According to official figures, 810000 housing units were built during the period from 1999-2004 (Ministère de l'Habitat et de l’Urbanisme, 2011).

\section{Algerian Housing Policies From 2001 to 2019}

The housing sector in this period had considerable priority and huge funds were dedicated to eliminating the housing crisis (Figure 3). This sought to improve the living conditions of Algerian society. In fact, since 2000, oil has played a significant role in launching major projects. Thus, the beginning of the third millennium was a new era where the public authorities in Algeria have gambled on economic development whereby national development plans were implemented aiming to improve the standard of living of individuals, develop education and generalise care health, building basic facilities and developing the infrastructure. Four national development plans have been launched since 2001 
Djafri Riadh, Mariana Mohamed Osman

Housing Crisis in Algeria: Challenges and Perspectives

as part of a series of investments in the public sector through the economic recovery support program for the period from 2001-2004. It was followed by the supplementary program to support economic growth for the period from 2005 2009 and the 2010-2014 five-year plan as well as the 2015-2019 five-year plan. Accordingly, these national development plans have a prominent and important role in achieving the objectives of financial policy represented in economic development and various sectors, including housing and improving the standard of living.

Therefore, the new era in Algeria has seen a sort of evolution in launching new national development plans to upgrade the living conditions and surpass the housing crisis. Concerning the housing sector, 3585572 units were completed between 2010 and 2017 (Services du Premier Ministre, 2017). Table 1 illustrates a summary of housing target and Achievement (1999-2019).

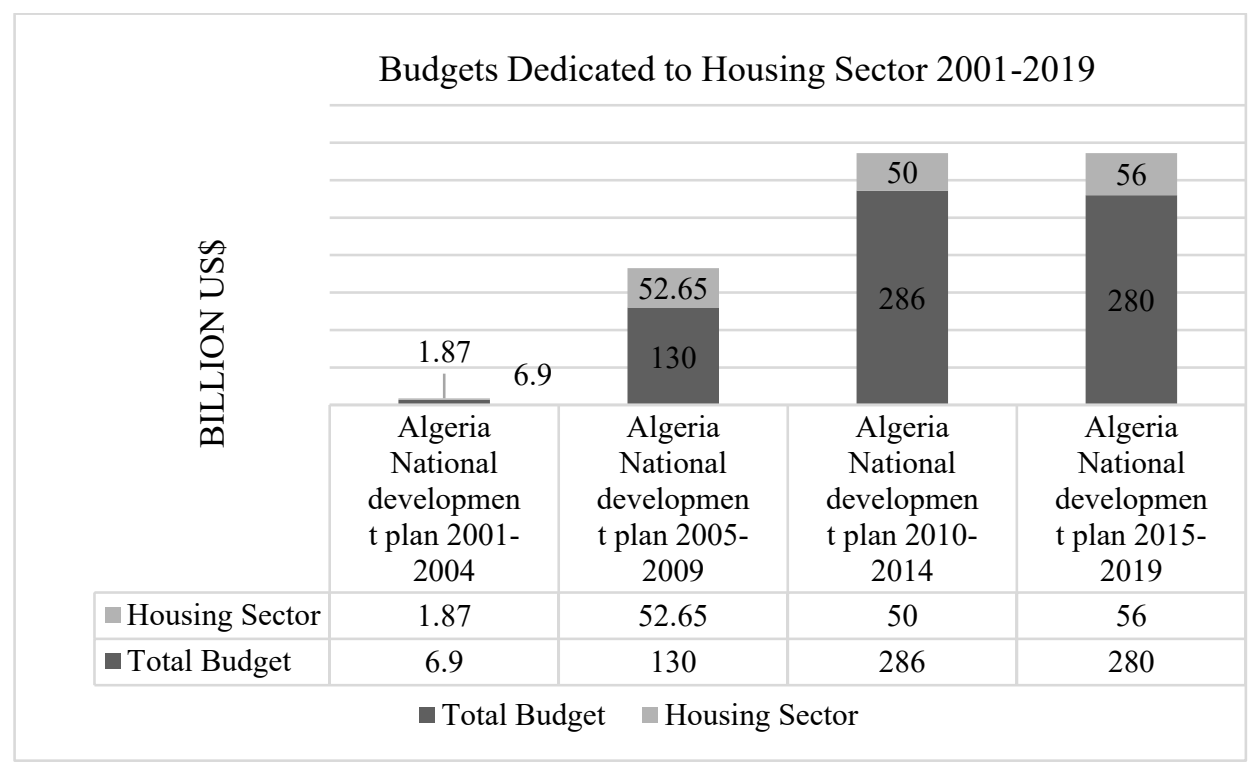

Figure 3: Budgets Dedicated to Housing Sector 2001-2019 Source: MHUV, 2019

Table1: Summary of Housing Target-Achievement in Algeria 1999-2019

\begin{tabular}{ccc}
\hline & Target (Units) & Achievement (Units) \\
$1999-2004$ & - & 810000 \\
$2005-2009$ & 1000000 & 1000000 \\
$2010-2014$ & 2000000 & 1200000 \\
$2015-2019$ & 1600000 & - \\
\hline
\end{tabular}


PLANNING MALAYSIA

Journal of the Malaysia Institute of Planners (2021)

In fact, the government is not able to respond to demand, in which the Algerian population is growing at an exponential rate with the rising urbanisation rate as the urban population has increased significantly from 1998 to 2019, reaching $72.60 \%$ (Worldometer, 2020). The Ministry of Housing established five subsidised types of housing programmes for high-, middle- and low-income to ease the crisis. The demand for these programmes is far exceeding supply, especially for low-income groups. In addition to the public sector housing, the private sector in Algeria is also working along to ease the housing issues by providing different types of housing throughout Algeria. Nevertheless, there has been a slight improvement in the average household size from 4.89 persons at the end of 2009 to 4.55 at the end of 2014. According to the National Algerian Office of Statistics, by 2030, the average household size would be 4.14 persons per housing unit. Figure 4 illustrates the average household size (1998-2030).

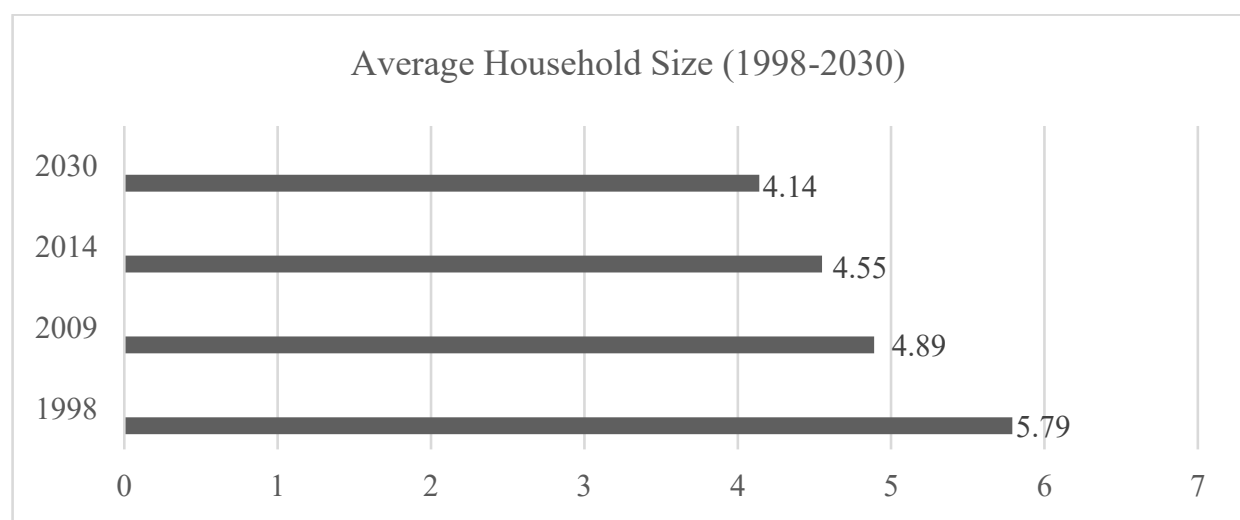

Figure 4: Average Household Size (1998-2030)

Source: Ministère de l'Habitat et de l'Urbanisme, 2011; ONS, 2019

Based on the figure, it can be inferred that the Algerian national housing policies are still far from reality to resolve the housing crisis. In purview of the housing policies' objectives, that aims to accommodate the low- and medium-income groups towards eliminating precarious housing, slum and shantytown. Thus, it appears that the current policies seem to be ineffective, despite the variety programmes, subsidies as well as encouragements from the private sectors.

\section{Housing Demand, Supply and Property Markets in Algeria}

According to Ismail, Jalil, \& Muzafar (2015) affordability of housing is based on a function of price and income. The income drives the demand, while the price depends on the interaction of both demand and supply. Further, numerous factors influence the demand and supply of housing. Demand factor includes:

i) Demographic factors, which consists of the analysis of the population growth, the number and the type of households. 
Djafri Riadh, Mariana Mohamed Osman

Housing Crisis in Algeria: Challenges and Perspectives

ii) The evaluation of households' income

iii) Policies implemented by the governments, which includes taxation and property rights.

iv) Occupants' preferences

Supply factor is affected by:

i) Land costs

ii) Government policy, which comprises land use and planning policy

iii) Cost of financing

iv) Construction costs including the costs of materials, equipment, and labour

In comparison to Malaysia, the government introduced various 5 years economic plans namely Malaysia Plan where in 2015-2020, the $11^{\text {th }}$ Malaysia Plan recommends establishing an integrated database on housing supply and housing conditions. The purpose is to offer adequate, comfortable, good quality, and affordable houses to improve the well-being of the people (Economic Planning Unit, 2015).

In Algeria, the policy of housing concentrates on building a large amount of very low-cost rental and subsidised housing units. The Ministère de l'Habitat de l'Urbanisme et de la Ville (2015) reported a national housing shortage of 720,000 units (Figure 5) and around $20 \%$ of the national housing stock was estimated to be vacant. Meanwhile, 2,500,000 units are in dangerous and poor conditions dated from independence in 1962. The demand continues to outstrip the supply with the growth of cities. This creates a need for affordable high-quality residential buildings. For the annual housing supply, it is estimated at 80,000 dwellings, while the annual demand is at 300,000 units.

Subsidised provision for low and medium groups constitutes the majority of the government's aid taking into account the variable incomes and the most disadvantaged families living in precarious or unhealthy conditions through providing a variety of housing programmes such as Social Housing, Rural Housing, Lease to Own Programme, and Assisted Housing Programme.

Most North African countries have a poor classification in terms of property registration according to the World Bank Group (2016), where Algeria ranked 109th with Morocco 87th, Tunisia 92nd, Egypt 162nd and Libya 187th performing worst. Several reasons behind informality in north African countries including poorly imposed regulations, shortages in housing supply, the lack of affordability, rapid urbanisation, low-income and focusing on high luxury units. In Algeria, limited land availability in some regions has severely restricted the growth of the formal real estate market. Most households depend on public housing programmes. Other strategies of the urban poor include self-building on informally-squatted government land and buying units in the informal market (Centre for affordable housing finance in Africa, 2017). 
Figure 5 shows the housing stock and deficit in Algeria from 1966 until 2019. The statistics illustrate that the housing stock increased slowly while the demand is still increasing over the past decades. Besides, the housing shortage registered at the highest level in 1999 with 3 million units. After that, the shortage decreased to 1.2 million and more than 720000 in 2010 and 2015 respectively. In 2018, the shortage registered 1.5 million units with a total of the housing stock of 9,634,967 units in 2019.

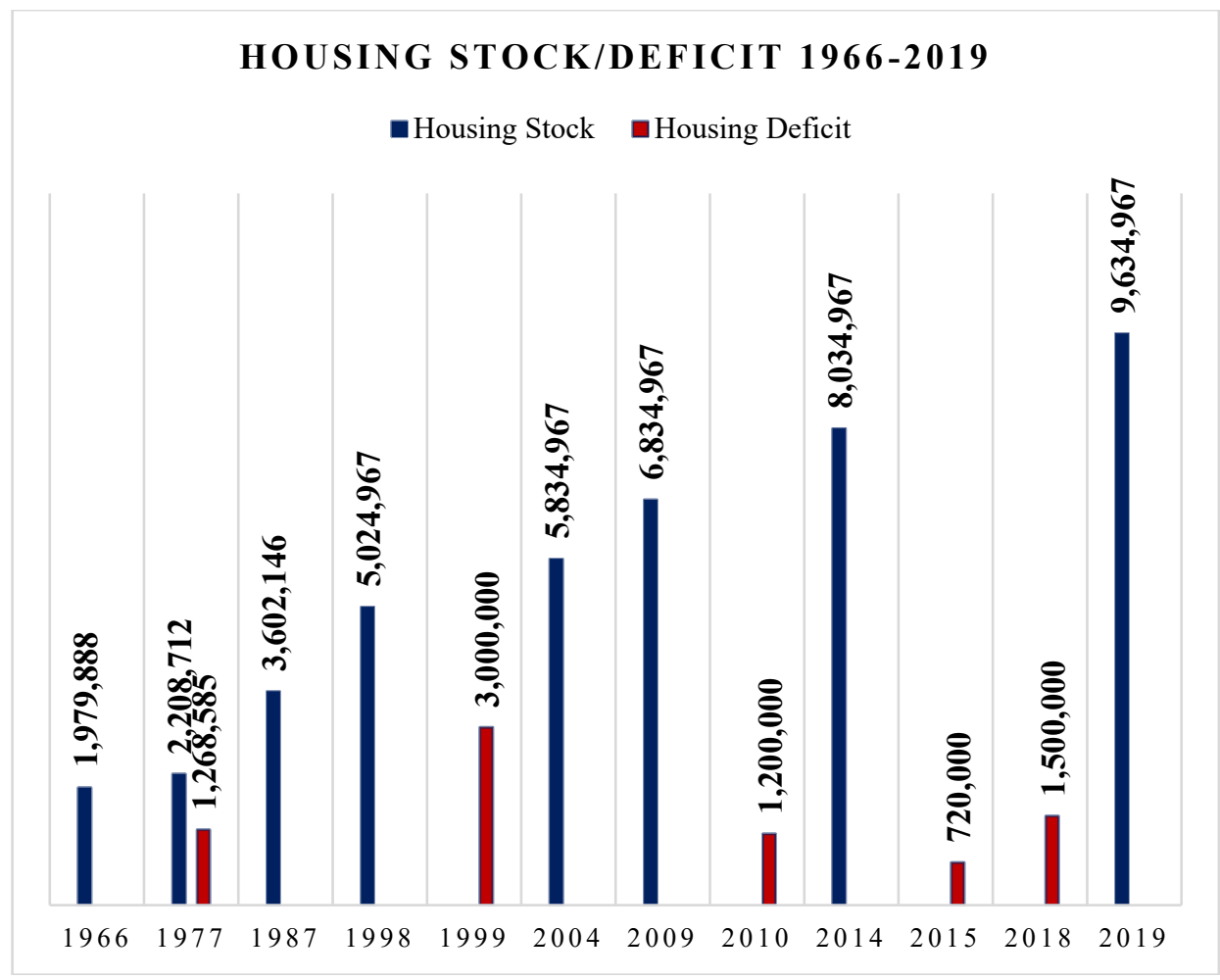

Figure 5: Housing Stock and Deficit in Algeria (1966-2019) Source: Adapted by the author from MHUV, 2019

\section{CONCLUSION}

Housing is an ongoing challenge that has faced Algeria since independence. The Algerian government is facing pressure to provide low- and medium-income housing to the fast-growing population. Further, Algeria has made considerable efforts to end the housing crisis by implementing various strategies and plans to tackle housing problems.

Algerian housing policies are currently poorly structured, thereby failing to meet the housing crisis. Therefore, a significant change in how these programmes is currently structured is urgent. In addition, it is necessary to assign 
Djafri Riadh, Mariana Mohamed Osman

Housing Crisis in Algeria: Challenges and Perspectives

monitors to tighten control over contractors in order to respect building standards while supporting housing complexes with various facilities. Besides, there is a need to find new forms to finance the construction of housing units in order to reduce dependence on the Public Treasury. Thus, the Algerian market should be open for investors.

To ensure improved performance of housing in addressing the encountered issues and solving the housing crisis, the following recommendations are made. First, refining the current housing policies implemented on national, regional, and local levels to enhance consistency of vision and encourage public participation. Second, developing quality and adequate housing to upgrade the overall housing quality in Algeria. Third, the control process during the construction and delivery of housing units is an important factor to ensure the construction completes on time and the distribution is equitable. Fourth, providing well-prepared specifications and guidelines defining the full process from the study to delivery. Fifth, the financial factor followed by professional management determines the quantity and quality as improving the current housing financing schemes will contribute to offering effective solutions for easy access to different housing programmes. Sixth, there is a mismatch in demand and supply for affordable housing according to the statistics. Hence, for efficient planning of housing supply and demand, there is a need to establish an integrated housing database for all relevant stakeholders and provide the needed information. Finally, there is a need to explore and examine the interrelationships between factors affecting housing problems in Algeria.

\section{REFERENCES}

Abdelkarim, H. (2012). Evolution des politiques de l'habitat en Algerie le L.S.P comme solution à la crise chronique du logement cas d'etude la ville de Chelghoum Laid. Université Ferhat Abbas Sétif, Algérie.

Algerian National Report on Housing. (2014). National Report on Housing for the Conference on Housing Habitat III. (July), 1-42. Retrieved from http://unhabitat.org/wp-content/uploads/2014/07/Algeria-National-Report.pdf

Behloul, M. (1991). Post occupancy evaluation of five story walk up dwellings: the case of four mass housing estates in Algiers. (University of Sheffield). Retrieved from http://etheses.whiterose.ac.uk/1872/

Bellal, T. (2009). Housing supply in Alegria: Affordability matters rather than availability. Theoretical and Empirical Researches in Urban Management, 4(3), $97-114$.

Benamrane, D. (1980). Crise de l'habitat perspective de développement socialiste en Algérie (SNED). Algiers.

Bendib, K., \& Naceur, F. (2018). Les tentatives de réappropriation des espaces extérieurs dans les cités de logements collectifs. Émergence d'une résidentialisation informelle? Cas de la ville de Batna (Algérie). Géocarrefour, 92(4).

Benmatti, N. A. (1982). L'Habitat du tiers-monde (cas de l'Algérie). Sned.

Centre for affordable housing finance in Africa. (2017). Housing Finance in Africa: A 
review of some of Africa's housing finance markets (8th ed.). Retrieved from https://housingfinanceafrica.org/app/uploads/CAHF_smallpdf.pdf?x77297

Djafri, R., Mohamed Osman, M., Rabe, N. S., \& Shuid, S. (2019). Algerian Housing Policies. Asian Journal of Environment-Behaviour Studies, 4(13), 1-14. https://doi.org/10.21834/aje-bs.v4i13.349

Djiar, K. A. (2014). Politiques de l'habitat en Algerie. Cinquante ans après (Al-Djazair). Alger.

Djiar, K. A., Gharbi, M., Messaoudene, M., \& Chareb, O. (2015). Urban Renewal, Social Housing, Relocation, and Violence in Algiers. International Journal of Architectural and Environmental Engineering, 9(4).

Economic Planning Unit. (2015). Eleventh Malaysia Plan 2016-2020: Anchoring Growth on People. Retrieved from http://www.sarawakdga.org.my/wpcontent/uploads/2015/09/11th_Malaysian_Plan.pdf

Guendouz, T., Gasmi, S., \& Belhimer, I. (2017). The Five-Year Development Plans in Algeria 2001-2014. Unemployment and Inflation. Human and Social Studies “مجلة در اسات انسانية واجتماعية, 7, 189-215.

Hadjri, K. (1992). Current Algerian housing policies affecting the methods for housing provision. Habitat International, 16(3), 71-78. https://doi.org/10.1016/01973975(92)90064-6

Ismail, S., Jalil, I. N., \& Muzafar., and P. M. M. (2015). Making Housing Affordable.

Lalonde, M. (2010). La crise du logement en Algérie: des politiques d'urbanisme mésadaptées. Université de Montréal.

Madani, S. Z. (2012). Le logement en algérie: programmes, enjeux et tensions. Confluences Méditerranée, 2(81), 133-152. https://doi.org/10.3917/come.081.0133

Merzag, H. (2015). Le logement social collectif: Entre la conception et l'usage Cas de la ville de M'sila. Mohamed khider-Biskra, Algeria. Doctoral thesis.

MHUV. (2018). Ministère de l'Habitat, de l'Urbanisme et de la Ville. Retrieved August 25, 2018, from http://www.mhuv.gov.dz/Pages/Article.aspx?a=79

MHUV. (2019). Ministère de l'Habitat, de l'Urbanisme et de la Ville. Retrieved December 16, 2019, from http://www.mhuv.gov.dz

Ministère de l'Habitat de l'Urbanisme et de la Ville. (2015). Politiuqe gouvernementale dans le domaine de l'habitat, de l'hurbanisme et de la ville. Retrieved from http://www.premier-ministre.gov.dz/fr (Accessed on 20 March 2018)

Ministère de l'Habitat et de l'Urbanisme. (2011). Agir pour les réduction du risque sismique. Revue de l'Habitat, 6.

Ministry of Housing. (1986). "Situation et Perspectives.” Algiers.

Mohdeb, R. (1988). L'espace habité et l'habitat dans la ville de Jijel (Algérie).

Mouaziz-Bouchentouf, N. (2018). Histoire et politique de l'habitat en Algérie. Cours. Retrieved from https:/www.univ-usto.dz/images/coursenligne/HPH.pdf (Accessed on 5 June 2018)

Naceur, F. (2013). Effects of outdoor shared spaces on social interaction in a housing estate in Algeria. Frontiers of Architectural Research, 2(4), 457-467. https://doi.org/10.1016/j.foar.2013.09.002

ONS. (2000). National Office of Statistics, Algeria.

ONS. (2017). National Office od Statistics, Algeria. 
Djafri Riadh, Mariana Mohamed Osman

Housing Crisis in Algeria: Challenges and Perspectives

ONS. (2019). National Office of Statistics, Algeria.

Oussadou, A. (1988). Residential satisifaction in the new urban housing projects in Algeria: a case study of Ain-Allah, Algiers. University of Nottingham. Doctoral thesis.

Oxford Business Group. (2017). Algeria to address the housing shortage | Algeria 2017 | Retrieved April 2, 2020, from https://oxfordbusinessgroup.com/overview/stockanswers-government-continues-address-housing-shortage

Saada, M. N. (1999). Housing Policy in Algeria. Issues and Perspectives. 1-14.

Services du Premier Ministre. (2017). Plan d'action du gouvernement pour la mise en cuvre du programme $d u$ president de la republique. Retrieved from http://www.premier-ministre.gov.dz/ressources/front/files/pdf/plans-dactions/plan-d-action-du-gouvernement-2017-fr.pdf (Accessed on 28 June 2018)

Tarache, A. (2009). Les facteurs déterminants la crise de logement en Algérie. Sciences Humaines, B (32), 67-80.

The World Bank Group. (2017). World development Indicators 2017. https://doi.org/10.1596/978-1-4648-0683-4

World Bank Group. (2016). Doing Business 2016 Measuring Regulatory Quality and Efficiency (13th Editi). https://doi.org/10.1596/978-1-4648-0667-4

Worldometer. (2020). Algeria Population (2020) - Worldometer. Retrieved February 2, 2020, from https://www.worldometers.info/world-population/algeria-population/

Received: $3^{\text {rd }}$ November 2021. Accepted: $5^{\text {th }}$ December 20 